\title{
Efficacy And Safety of Ramucirumab and Docetaxel In Previously Treated Patients With Squamous Cell Lung Cancer: A Multicenter Retrospective Cohort Study
}

Hayato Kawachi ( $\sim$ kwhat0729@gmail.com )

Osaka International Cancer Institute: Osaka Kokusai Gan Center https://orcid.org/0000-0002-16732260

Motohiro Tamiya

Osaka International Cancer Institute: Osaka Kokusai Gan Center

Kinnosuke Matsumoto

Kinki Chuo Chest Medical Center: Kokuritsu Byoin Kiko Kinki Chuo Kokyuki Center

Akihiro Tamiya

Kinki Chuo Chest Medical Center: Kokuritsu Byoin Kiko Kinki Chuo Kokyuki Center

Takafumi Yanase

Osaka Prefectural Habikino Hospital: Osaka Habikino Iryo Center

\section{Satoshi Tanizaki}

Osaka General Medical Center: Osaka Kyuseiki Sogo Iryo Center

\section{Toru Kumagai}

Osaka International Cancer Institute: Osaka Kokusai Gan Center

\section{Research Article}

Keywords: Ramucirumab, Non-small cell lung cancer, Treatment outcome, Squamous cell carcinoma

Posted Date: November 18th, 2021

DOI: https://doi.org/10.21203/rs.3.rs-1057060/v1

License: (c) (i) This work is licensed under a Creative Commons Attribution 4.0 International License.

Read Full License

Version of Record: A version of this preprint was published at Investigational New Drugs on January 13th, 2022. See the published version at https://doi.org/10.1007/s10637-022-01214-w. 


\section{Abstract}

Objective: Ramucirumab plus docetaxel therapy (RAM/DOC) is currently the standard for previously treated advanced non-small cell lung cancer (NSCLC), irrespective of histology. However, the safety data of anti-angiogenic agents for squamous cell NSCLC (Sq) is lacking, with a higher reported rate of severe hemoptysis in a clinical trial setting. We conducted a multicenter retrospective cohort study to confirm the efficacy and safety of RAM/DOC for Sq in real-world settings.

Methods: We retrospectively analyzed previously treated patients with advanced NSCLC who underwent RAM/DOC at four institutions. Clinical data on the initiation of RAM/DOC were collected from medical records. Treatment outcomes of RAM/DOC were assessed according to the Response Evaluation Criteria in Solid Tumors version 1.1. Incidence of pulmonary hemorrhage was assessed according to the Common Terminology Criteria for Adverse Events version 5.0.

Results: Overall, 237 patients with NSCLC were included and $38(16 \%)$ had squamous cell carcinoma. There were no significant differences in median progression-free survival and overall survival between $\mathrm{Sq}$ and non-Sq patients (5.8 months vs. 4.3 months, $P=0.0937 ; 15.2$ months vs. 13.4 months, $P=0.714$, respectively). Of all patients, $13(5 \%)$ developed pulmonary hemorrhage. According to histology, there was no significant difference in pulmonary hemorrhage proportion between $\mathrm{Sq}$ and non-Sq cohorts (2/38 vs. $11 / 199$, respectively, $P=0.947)$.

Conclusion: For previously treated patients with Sq, efficacy and safety data of RAM/DOC were confirmed in a real-world setting and were similar to non-Sq. Ramucirumab is the only vascular endothelial growth factor-blocker available for Sq.

\section{Introduction}

Lung cancer is a major cause of cancer-related mortality worldwide [1]. Non-small cell lung cancer (NSCLC) accounts for approximately $80 \%$ of all lung cancer cases, with the majority of NSCLC cases being diagnosed at advanced, unresectable, and metastatic disease stages [2]. Systemic chemotherapy is the standard anticancer treatment for advanced metastatic NSCLC. Currently, genetic and genomic profiling has developed, and advancements in molecular targeted therapies have improved the prognosis of patients with NSCLC [3]. Furthermore, immune checkpoint inhibitors (ICls) and programmed death 1 (PD-1) programmed death ligand 1 (PD-L1) axis and cytotoxic T-lymphocyte antigen 4 (CTLA-4) axis inhibitors have demonstrated outstanding efficacy for first-line treatment of metastatic NSCLC, and they have been established as novel standard treatment options for NSCLC [4-12]. Despite an initial dramatic response and durable progression-free survival (PFS) using these agents, progressive disease (PD) is inevitable in most patients. Therefore, second-line chemotherapy after PD as first-line treatment is still important as salvage therapy.

Ramucirumab is a fully human recombinant IgG1 monoclonal antibody that specifically binds to the vascular endothelial growth factor (VEGF) receptor-2 extracellular domain with high affinity [13]. In a 
preclinical study, VEGF blockade caused transient vascular normalization, leading to an enhanced effect of chemotherapy. In a large phase III trial, REVEL trial, ramucirumab plus docetaxel (RAM/DOC) therapy demonstrated improved overall survival (OS), PFS, and objective response rate (ORR) compared to placebo plus docetaxel for NSCLC patients with disease progression after first-line platinum-based chemotherapy [14]. Based on this result, RAM/DOC therapy has been approved and considered as one of the standard treatments for second-line therapy of metastatic NSCLC regardless of histology.

RAM/DOC therapy has been shown to be effective and safe in clinical trials; however, these clinical trials have eligibility criteria that outline who can participate in attempts of achieving accurate and meaningful results. Therefore, only limited patients in good general condition without organ failure can participate. Clinical trial outcomes are therefore not entirely representative of real-world patients [15]. Previous studies have shown that the majority of NSCLC patients in clinical settings are ineligible for clinical trials, with poorer treatment outcomes and higher toxicity rates in these ineligible patients [16, 17]. In particular, the safety of anti-angiogenic agents for squamous cell NSCLC (Sq) is controversial because a higher rate of severe hemoptysis was noted in Sq compared with adenocarcinoma in a randomized phase II study of bevacizumab, as another anti-VEGF agent approved for NSCLC. Consequently, the use of bevacizumab in squamous cell NSCLC has been routinely avoided [18]. Thus, we conducted a multicenter retrospective cohort study on the proportion, clinical characteristics, and prognoses of previously treated NSCLC patients who were administered RAM/DOC to confirm its efficacy and safety in the real-world setting, which provides a wider variety of patient characteristics compared to a clinical trial setting.

\section{Patients And Methods}

In this retrospective multicenter cohort study, we included consecutive previously treated patients with advanced NSCLC (unresectable stage III or IV, including postoperative recurrence) who received RAM/DOC at four institutions in Japan between June 2016 and March 2020.

Clinical data at the time of initiating DOC/RAM were collected from electronic medical records, including age, sex, smoking status, Eastern Cooperative Oncology Group performance status (ECOG-PS) score, histology (Sq and non-Sq), EGFR mutation, PD-L1 status, treatment line history of prior ICI therapy, and history of prophylactic administration of pegylated-granulocyte-colony stimulating factor (PEG-G-CSF). The incidence of pulmonary hemorrhage was assessed according to the Common Terminology Criteria for Adverse Events (CTCAE) version 5.0 [19]. Tumor assessment was performed according to the Response Evaluation Criteria in Solid Tumors (RECIST version 1.1 [20]. PFS was calculated from the start of RAM/DOC treatment until the first instance of lung cancer progression or death due to any cause. Overall survival (OS) was calculated from the start of DOC/RAM treatment until the first instance of death from any cause. The data cut-off date was June 30,2020. Our study protocol was approved by the respective review boards of each of the four institutions. Patient consent was waived due to the retrospective nature of the study, and we used an opt-out method so that patients and families could refuse to participate in the study. 


\section{Statistical analysis}

The Kaplan-Meier method was used to estimate survival outcomes and groups, according to metastatic organs, were compared using the log-rank test. Cox proportional hazard models were used to determine associations between patient characteristics and survival outcomes. Only factors with a P-value of $<0.10$ on univariate analysis were included in the multivariate analysis. Results were expressed as hazard ratios (HRs) with 95\% confidence intervals (Cls). Statistical significance was defined as having a two-tailed Pvalue of $<0.05$. All analyses were performed using JMP 14 software (SAS Institute, Cary, NC, USA).

\section{Results}

\subsection{Patient characteristics}

A total of 237 previously treated patients with NSCLC were included in the study; 38 (16\%) had squamous cell carcinoma on histology (Table 1). The median patient age was 66 years (range, 33-82 years). The majority were men (63\%), had a smoking history (76\%), and had an ECOG PS score of 0 or $1(80 \%)$. At the time of administering RAM/DOC, 64 (27\%) patients were treated with RAM/DOC as second-line treatment, while $124(52 \%)$ patients had previously been treated with ICls. PEG-G-CSF was prophylactically administered to 190 patients (80\%). 
Table 1

Patient characteristics.

\begin{tabular}{|c|c|c|c|c|}
\hline Patient characteristics & $\begin{array}{l}\text { Total (\%) } \\
(\mathrm{N}=237)\end{array}$ & $\begin{array}{l}\text { Squamous cell } \\
\text { carcinoma (\%) } \\
(\mathrm{N}=38)\end{array}$ & $\begin{array}{l}\text { Non-Squamous } \\
\text { cell carcinoma (\%) } \\
(\mathrm{N}=199)\end{array}$ & P-value \\
\hline \multicolumn{5}{|l|}{ Age (years) } \\
\hline Median (range) & $66(33-82)$ & $69(54-80)$ & $66(33-82)$ & 0.020 \\
\hline \multicolumn{5}{|l|}{ Age group } \\
\hline$\geqq 75$ years & $30(13)$ & $7(18)$ & $23(12)$ & 0.244 \\
\hline$<75$ years & $207(87)$ & $31(82)$ & $176(88)$ & \\
\hline \multicolumn{5}{|l|}{ Sex } \\
\hline Male & $150(63)$ & $32(84)$ & $118(59)$ & 0.003 \\
\hline Female & $87(37)$ & $6(16)$ & $81(41)$ & \\
\hline \multicolumn{5}{|l|}{ Smoking status } \\
\hline Never-smoker & $58(24)$ & $0(0)$ & $58(29)$ & $<0.001$ \\
\hline Current or former smoker & $179(76)$ & $38(100)$ & $141(71)$ & \\
\hline \multicolumn{5}{|l|}{ ECOG PS } \\
\hline $0-1$ & $189(80)$ & $33(87)$ & $156(78)$ & 0.235 \\
\hline $2-4$ & $48(20)$ & $5(13)$ & $43(22)$ & \\
\hline \multicolumn{5}{|l|}{ Histology } \\
\hline Squamous cell carcinoma & $38(16)$ & $38(100)$ & & \\
\hline Adenocarcinoma & $180(76)$ & & $180(90)$ & \\
\hline Other & $19(8)$ & & $19(10)$ & \\
\hline \multicolumn{5}{|l|}{ EGFR mutation status } \\
\hline Positive & $66(28)$ & $0(0)$ & $66(33)$ & $<0.001$ \\
\hline Negative or not investigated & $171(72)$ & $38(100)$ & $133(67)$ & \\
\hline \multicolumn{5}{|l|}{ PD-L1 status } \\
\hline$\geqq 50 \%$ & $31(13)$ & $10(26)$ & $21(11)$ & \\
\hline
\end{tabular}

ECOG PS, Eastern Cooperative Oncology Group Performance Status; EGFR, epidermal growth factor receptor gene; PD-L1, programmed death ligand 1; ICl, immune checkpoint inhibitor; G-CSF, granulocyte-colony stimulating factor. 


\begin{tabular}{|c|c|c|c|c|}
\hline Patient characteristics & $\begin{array}{l}\text { Total (\%) } \\
(\mathrm{N}=237)\end{array}$ & $\begin{array}{l}\text { Squamous cell } \\
\text { carcinoma (\%) } \\
(\mathrm{N}=38)\end{array}$ & $\begin{array}{l}\text { Non-Squamous } \\
\text { cell carcinoma (\%) } \\
(\mathrm{N}=199)\end{array}$ & P-value \\
\hline $1-49 \%$ & $69(29)$ & $13(34)$ & $56(28)$ & \\
\hline$<1 \%$ & $65(27)$ & $5(13)$ & $60(30)$ & \\
\hline Not evaluated & $72(30)$ & $10(26)$ & $62(31)$ & \\
\hline \multicolumn{5}{|l|}{ Treatment line } \\
\hline second line & $64(27)$ & $10(26)$ & $54(27)$ & 0.917 \\
\hline third or later line & 173(73) & $28(74)$ & $145(73)$ & \\
\hline \multicolumn{5}{|l|}{ Prior ICI therapy } \\
\hline Administered & $124(52)$ & $33(87)$ & $91(46)$ & $<0.001$ \\
\hline ICI monotherapy & $116(49)$ & $32(84)$ & $84(42)$ & \\
\hline ICI plus chemotherapy & $14(6)$ & $3(8)$ & $11(6)$ & \\
\hline None & $113(48)$ & $5(13)$ & $108(54)$ & \\
\hline \multicolumn{5}{|l|}{ Prophylactic G-CSF } \\
\hline Administered & $190(80)$ & $32(84)$ & $158(79)$ & 0.495 \\
\hline None & $47(20)$ & $6(16)$ & $41(21)$ & \\
\hline
\end{tabular}

Patients with squamous cell carcinoma had significantly higher proportions of those with older age (69 years vs. 66 years, respectively, $P=0.020)$, male sex (32/38 vs. $118 / 199$, respectively, $P=0.003)$, smoking history (38/38 vs. $141 / 199$, respectively, $P<0.001)$, no EGFR mutation status (0/38 vs. 66/199, respectively, $P<0.001)$, and prior ICl therapy history (33/38 vs. 91/199, respectively, $P<0.001)$.

\subsection{Treatment outcomes}

In all patients, the objective response rate (ORR) and disease control rate (DCR) was $25 \%$ and $64 \%$, respectively (Table 2). At the time of analysis, the median PFS and OS were 4.5 months ( $95.0 \%$ Cl: $3.6-$ 5.5 months) and 13.4 months (95.0\% Cl: 11.5-15.6 months), respectively (Fig. 1A and Fig. 1B). 
Table 2

Treatment outcome for Docetaxel plus Ramucirumab.

\begin{tabular}{|lllll|}
\hline & $\begin{array}{l}\text { All } \\
\text { patients } \\
(\mathbf{\%})\end{array}$ & $\begin{array}{l}\text { Squamous cell } \\
\text { carcinoma (\%) } \\
(\mathbf{N}=\mathbf{N}=\mathbf{3 8})\end{array}$ & $\begin{array}{l}\text { Non-Squamous cell } \\
\text { carcinoma (\%) } \\
\mathbf{( N = 1 9 9 )}\end{array}$ & $\begin{array}{l}\text { P- } \\
\text { value }\end{array}$ \\
\hline $\begin{array}{l}\text { Response to Docetaxel plus } \\
\text { Ramucirumab }\end{array}$ & & & \\
\hline Complete Response & $2(1)$ & $1(3)$ & $1(1)$ \\
\hline Partial Response & $56(24)$ & $9(24)$ & $47(24)$ \\
\hline Stable Disease & $89(38)$ & $17(45)$ & $72(36)$ \\
\hline Progression Disease & $83(35)$ & $10(26)$ & $6(37)$ \\
\hline Not Evaluable & $7(3)$ & $1(3)$ & $48(25)$ \\
\hline Objective Response & $58(25)$ & $10(27)$ & $120(62)$ \\
\hline Disease Control & $\begin{array}{l}147 \\
(64)\end{array}$ & $27(72)$ & 0.782 \\
\hline
\end{tabular}

We also investigated treatment outcomes according to histology. The ORR and DCR were not significantly different between the Sq and non-Sq groups ( $27 \%$ vs. $25 \%, P=0.782 ; 72 \%$ vs. $62 \%, P=0.210$, respectively) (Table 2). Additionally, there were no significant differences in the median PFS and OS between the Sq and non-Sq groups (5.8 months vs. 4.3 months, $P=0.0937 ; 15.2$ months vs 13.4 months, $P=0.714$, respectively) (Fig. 2A and Fig. 2B).

The PFS according to patient characteristics is shown in Table 3. Univariate analysis using Cox proportional hazards models indicated that a good ECOG PS (HR, 0.57, 95.0\% Cl: $0.40-0.81 ; P=0.002)$ was significantly associated with a longer PFS. In contrast, factors not significantly associated with a longer PFS were: age (HR: 0.98, 95.0\% Cl: 0.63-1.51; $P=0.914$ ), sex (HR: 1.21, 95.0\% Cl: 0.90-1.62; $P=0.197$ ), smoking status (HR: $0.76,95.0 \% \mathrm{Cl}: 0.55-1.06$; $P=0.103$ ), histology (HR: $0.72,95.0 \% \mathrm{Cl}: 0.49-$ 1.06; $P=0.096$ ), EGFR mutation (HR: 1.19, 95.0\% Cl: 0.87-1.62; $P=0.267)$, treatment line (HR: $1.03,95.0 \%$ Cl: $0.75-1.42 ; P=0.840)$, prior ICl treatment history (HR: $0.81,95.0 \% \mathrm{Cl}: 0.61-1.08 ; P=0.146)$, and prophylactic G-CSF administration history (HR: 0.98, 95.0\% Cl: 0.72-1.45; $P=0.919$ ). Furthermore, on the multivariate Cox proportional hazards regression model, only a good ECOG PS (HR, 0.56, 95.0\% Cl: 0.38$0.81 ; P=0.002$ ) was an independent predictor of longer PFS in patients treated with RAM/DOC. 
Table 3

Analyses of progression free survival time ( $\mathrm{N}=237)$.

\begin{tabular}{|c|c|c|c|c|c|c|}
\hline \multirow[t]{2}{*}{ Characteristics } & \multirow{2}{*}{$\begin{array}{l}\text { No of } \\
\text { patients } \\
(\%)\end{array}$} & \multirow{2}{*}{$\begin{array}{l}\text { Progression free } \\
\text { survival time } \\
\text { (months) }\end{array}$} & \multicolumn{2}{|l|}{ Univariate } & \multicolumn{2}{|c|}{ Multivariate } \\
\hline & & & $\begin{array}{l}\mathrm{HR}(95 \% \\
\mathrm{Cl})\end{array}$ & $\begin{array}{l}\mathrm{P}- \\
\text { value }\end{array}$ & $\begin{array}{l}\mathrm{HR}(95 \% \\
\mathrm{Cl})\end{array}$ & $\begin{array}{l}\mathrm{P} \text { - } \\
\text { value }\end{array}$ \\
\hline $\begin{array}{l}\text { Age } \\
\geq 75 \text { years } \\
<75 \text { years }\end{array}$ & $\begin{array}{l}30(13) \\
207(87)\end{array}$ & $\begin{array}{l}5.8 \\
4.4\end{array}$ & $\begin{array}{l}0.98(0.63- \\
1.51) \\
\text { reference }\end{array}$ & 0.914 & $\begin{array}{l}1.02 \\
(0.65- \\
1.60) \\
\text { reference }\end{array}$ & 0.942 \\
\hline $\begin{array}{l}\text { Sex } \\
\text { Male } \\
\text { Female }\end{array}$ & $\begin{array}{l}150(63) \\
87(37)\end{array}$ & $\begin{array}{l}4.1 \\
5.3\end{array}$ & $\begin{array}{l}1.21(0.90- \\
1.62) \\
\text { reference }\end{array}$ & 0.197 & $\begin{array}{l}1.25 \\
(0.86- \\
1.82) \\
\text { reference }\end{array}$ & 0.243 \\
\hline $\begin{array}{l}\text { Smoking status } \\
\text { Never-smoke } \\
\text { current or former } \\
\text { smoker }\end{array}$ & $\begin{array}{l}58(24) \\
179(76)\end{array}$ & $\begin{array}{l}6.3 \\
4.1\end{array}$ & $\begin{array}{l}0.76(0.55- \\
1.06) \\
\text { reference }\end{array}$ & 0.103 & $\begin{array}{l}0.73 \\
(0.47- \\
1.12) \\
\text { reference }\end{array}$ & 0.152 \\
\hline $\begin{array}{l}\text { ECOG PS } \\
0-1 \\
2-4\end{array}$ & $\begin{array}{l}189(80) \\
48(20)\end{array}$ & $\begin{array}{l}5.5 \\
2.8\end{array}$ & $\begin{array}{l}0.57(0.40- \\
0.81) \\
\text { reference }\end{array}$ & 0.002 & $\begin{array}{l}0.56 \\
(0.38- \\
0.81) \\
\text { reference }\end{array}$ & 0.002 \\
\hline $\begin{array}{l}\text { Histology } \\
\text { Squamous cell } \\
\text { carcinoma } \\
\text { Non-squamous cell } \\
\text { carcinoma }\end{array}$ & $\begin{array}{l}38(16) \\
199(84)\end{array}$ & $\begin{array}{l}5.8 \\
4.3\end{array}$ & $\begin{array}{l}0.72(0.49- \\
1.06) \\
\text { reference }\end{array}$ & 0.096 & $\begin{array}{l}0.75 \\
(0.49- \\
1.14) \\
\text { reference }\end{array}$ & 0.178 \\
\hline $\begin{array}{l}\text { EGFR mutation } \\
\text { Yes } \\
\text { No or not } \\
\text { investigated }\end{array}$ & $\begin{array}{l}66(28) \\
171(72)\end{array}$ & $\begin{array}{l}4.1 \\
4.8\end{array}$ & $\begin{array}{l}1.19(0.87- \\
1.62)\end{array}$ & 0.267 & $\begin{array}{l}1.29 \\
(0.86- \\
1.93) \\
\text { reference }\end{array}$ & 0.227 \\
\hline $\begin{array}{l}\text { Treatment line } \\
\text { second line } \\
\text { Third or later line }\end{array}$ & $\begin{array}{l}64(27) \\
173(73)\end{array}$ & $\begin{array}{l}4.3 \\
4.5\end{array}$ & $\begin{array}{l}1.03(0.75- \\
1.42) \\
\text { reference }\end{array}$ & 0.840 & $\begin{array}{l}1.01 \\
(0.67- \\
1.55) \\
\text { reference }\end{array}$ & 0.945 \\
\hline
\end{tabular}

ECOG PS, Eastern Cooperative Oncology Group Performance Status; EGFR, epidermal growth factor receptor gene; ICl, immune checkpoint inhibitor; G-CSF, granulocyte-colony stimulating factor; HR, hazard risk; $\mathrm{Cl}$, confidence interval. 


\begin{tabular}{|c|c|c|c|c|c|c|}
\hline \multirow[t]{2}{*}{ Characteristics } & \multirow{2}{*}{$\begin{array}{l}\text { No of } \\
\text { patients } \\
(\%)\end{array}$} & \multirow{2}{*}{$\begin{array}{l}\text { Progression free } \\
\text { survival time } \\
\text { (months) }\end{array}$} & \multicolumn{2}{|l|}{ Univariate } & \multicolumn{2}{|c|}{ Multivariate } \\
\hline & & & $\begin{array}{l}\mathrm{HR}(95 \% \\
\mathrm{Cl})\end{array}$ & $\begin{array}{l}\mathrm{P} \text { - } \\
\text { value }\end{array}$ & $\begin{array}{l}\mathrm{HR}(95 \% \\
\mathrm{Cl})\end{array}$ & $\begin{array}{l}\mathrm{P} \text { - } \\
\text { value }\end{array}$ \\
\hline Prior ICI treatment & $124(52)$ & 5.1 & \multirow{2}{*}{$\begin{array}{l}0.81(0.61- \\
1.08) \\
\text { reference }\end{array}$} & \multirow[t]{2}{*}{0.146} & \multirow{2}{*}{$\begin{array}{l}0.83 \\
(0.58- \\
1.20)\end{array}$} & \multirow[t]{2}{*}{0.327} \\
\hline $\begin{array}{l}\text { Administered } \\
\text { None }\end{array}$ & $113(48)$ & 4.1 & & & & \\
\hline Prophylactic G-CSF & $190(80)$ & 4.5 & \multirow{2}{*}{$\begin{array}{l}0.98(0.72- \\
1.45)\end{array}$} & \multirow[t]{2}{*}{0.919} & \multirow{2}{*}{$\begin{array}{l}0.98 \\
(0.68- \\
1.41)\end{array}$} & \multirow[t]{2}{*}{0.919} \\
\hline $\begin{array}{l}\text { Administered } \\
\text { None }\end{array}$ & $47(20)$ & 4.8 & & & & \\
\hline $\begin{array}{l}\text { ECOG PS, Eastern Cc } \\
\text { receptor gene; ICl, im } \\
\text { hazard risk; Cl, confic }\end{array}$ & $\begin{array}{l}\text { erative } 0 \\
\text { ne checl } \\
\text { ce interv }\end{array}$ & $\begin{array}{l}\text { ogy Group Perfo } \\
\text { t inhibitor; G-CS }\end{array}$ & $\begin{array}{l}\text { e Status; E } \\
\text { ulocyte-col }\end{array}$ & $\begin{array}{l}\text { R, epi } \\
\text { y stim }\end{array}$ & $\begin{array}{l}\text { nal growt } \\
\text { ting facto }\end{array}$ & ctor \\
\hline
\end{tabular}

\subsection{Adverse events of pulmonary hemorrhage}

Of the 237 patients, $13(5 \%)$ developed pulmonary hemorrhage of any grade (eight patients had grade 1 , four had grade 2 , and one had grade 5). There was no significant difference regarding the proportion of patients who developed pulmonary hemorrhage of any grade between the Sq and non-Sq groups (2/38 vs. $11 / 199$, respectively, $P=0.947)$, nor in those who developed grade $\geq 3$ hemorrhage $(0 / 38$ vs. 1/199, respectively, $P=0.662$ ).

\section{Discussion}

In this study, we demonstrated treatment outcomes of RAM/DOC in previously treated patients with NSCLC in a real-world setting. Additionally, we found that RAM/DOC was a suitable treatment for both Sq and non-Sq in clinical settings, in terms of effectiveness and tolerability.

The results of the present study revealed that the treatment outcome in a real-world setting was consistent with the efficacy data reported from previous key clinical trials [14, 21]. Since the eligibility criteria of clinical trials have become increasingly detailed and strict, only selected patients in good general condition can participate [15]. Therefore, clinical trial outcomes may not be entirely representative of outcomes in real-world scenarios and careful attention should be paid to these differences when applying clinical trial data to real-world patients. In the REVEL and JVCG trials, only patients with disease progression despite first-line platinum-based therapy were included [14, 21]. Recently, ICI monotherapy or combination therapy has become the standard of care as a first-line treatment for patients with advanced NSCLC [4-12]. Therefore, it is still unknown whether these clinical trial data can be applied to patients who were previously treated with $\mathrm{ICl}$ or with more than one chemotherapy regimen, although this question seems to be an important problem in clinical practice settings. In our study, we found that both ICI treatment history and multi-line chemotherapy treatment history did not negatively affect treatment 
outcome, but the patients with poor ECOG PS being the only independent predictor of a shorter PFS. Based on this data, RAM/DOC is considered a reasonable treatment option, irrespective of prior treatment history.

Our study highlighted the efficacy and safety of RAM/DOC in patients with Sq. In the present study, outcomes regarding ORR, DCR, PFS, and OS were not significantly different between the Sq and non-Sq groups. Since the evidence for kinase inhibitors in Sq was substantially restricted, compared with non-Sq, the treatment options for Sq are still limited [22]. Therefore, it is considered important to confirm the efficacy data for Sq patients treated with RAM/DOC in a real-world setting. Whereas, RAM/DOC in realworld setting revealed that the frequency of treatment-related pulmonary hemorrhage was not associated with histology, which seemed to be unique as the previous trial of bevacizumab, another anti-VEGF antibody increased that in Sq-group. It is well known that blockade are different; bevacizumab binds to VEGF-A and interferes with the interaction between VEGF-A and VEGFR-2, whereas ramucirumab targets VEGFR-2 [23]. However, the reason for the difference of risk against pulmonary hemorrhage in Sq between ramucirumab and bevacizumab treatment remains unclear. Clarifying the precise mechanism may provide clues for safer treatment strategies with antiangiogenic agents for NSCLC. Further studies are needed.

Our study demonstrated the efficacy and safety data of ramucirumab for $\mathrm{Sq}$ in a real-world setting, which may provide a novel treatment strategy combined with VEGF inhibitors for Sq. In a preclinical study, VEGF inhibitors caused transient vascular normalization, leading to reduced tumor hypoxia and increased immune-cell infiltration, which modulates and reprograms the immunosuppressive tumor microenvironment, which may lead to increased antitumor immunity [24-26]. Therefore, ICls plus VEGF inhibitors are considered a reasonable combination treatment option. In a phase 3 clinical trial, chemotherapy combined with atezolizumab and bevacizumab demonstrated significantly longer survival compared to platinum doublet chemotherapy and established standard therapies in treatment-naïve advanced non-Sq patients [8]. Furthermore, to clarify the effect of adding a VEGF inhibitor to ICI plus chemotherapy more precisely, a randomized phase 3 study for non-Sq patients has been conducted [27]. These findings in a clinical setting support the benefit of such combination therapy; however, this treatment strategy is eligible for only non-Sq patients. Since ramucirumab is the only anti-angiogenic agent available for $\mathrm{Sq}$, combination with $\mathrm{ICl}$ and ramucirumab may be a reasonable treatment option for Sq. A phase 1 study revealed a manageable safety profile of first-line therapy with ramucirumab plus pembrolizumab in patients with NSCLC, including Sq [28]. Further studies are warranted to validate the efficacy of this combination treatment for Sq.

The present study had several limitations. First, this study had a multicenter retrospective design. Therefore, although the results of our study were clinically important, selection bias was inevitable. Second, this study included only Japanese patients, which precludes the generalization of our findings to patients from other countries. 
In conclusion, the results of the present study revealed the efficacy and safety data of RAM/DOC for previously treated patients with Sq and non-Sq in a real-world setting. Ramucirumab is the only VEGFblocker available for Sq. Further studies are needed to investigate novel combination therapies for Sq.

\section{Declarations}

\section{Author Declarations}

Ethics approval and consent to participate: All procedures performed in studies involving human participants were in accordance with the ethical standards of the institutional and/or national research committee and with the 1964 Helsinki declaration and its later amendments or comparable ethical standards. The study protocol was approved by the review board of each of the four institutions.

Consent for publication: The patient's informed consent was waived for the retrospective nature of study, and we used an opt-out method so that patients and families could refuse to participate in the study.

Availability of data and materials: The datasets during the current study available from the corresponding author on reasonable request.

Competing interests: Hayato Kawachi reports personal fees from Ono Pharmaceutical, personal fees from Chugai Pharmaceutical, personal fees from AstraZeneca, personal fees from Taiho Pharmaceutical, personal fees from Eli Lilly, personal fees from MSD, outside the submitted work. Motohiro Tamiya reports grants and personal fees from Boehringer Ingelheim, grants and personal fees from Ono Pharmaceutical, grants and personal fees from Bristol-Myers Squibb, personal fees from Chugai Pharmaceutical, personal fees from AstraZeneca, personal fees from Taiho Pharmaceutical, personal fees from Eli Lilly, personal fees from Asahi Kasei Pharmaceutical, personal fees from MSD, outside the submitted work. HS reports personal fees from Chugai Pharmaceutical, personal fees from MSD, personal fees from AstraZeneca, outside the submitted work. Akihiro Tamiya reports personal fees from Chugai Pharmaceutical, grants and personal fees from AstraZeneca, personal fees from Boehringer Ingelheim, grants and personal fees from Ono Pharmaceutical, grants and personal fees from Bristol-Myers Squibb, personal fees from MSD, personal fees from Taiho Pharmaceutical, personal fees from Pfizer, personal fees from Eli Lilly, personal fees from Takeda Pharmaceutical, personal fees from Kissei, personal fees from Amgen, personal fees from Merck Bio Pharma, outside the submitted work. Toru Kumagai reports grants and personal fees from Ono Pharmaceutical, grants from MSD, grants and personal fees from Chugai Pharmaceutical, grants and personal fees from AstraZeneca, grants and consulting fees from Takeda Pharmaceutical, consulting fees from Nitto Denko Corporation, grants and personal fees from Eli Lilly, grants from Merck Bio Pharma, grants and personal fees from Pfizer, grants and personal fees from Boehringer Ingelheim, grants and personal fees from Taiho Pharmaceutical, personal fees from Bristol-Myers Squibb, personal fees from Novartis Pharma, grants from The Osaka Foundation for The Prevention of Cancer and Lifestyle related Diseases (Public Interest Incorporated Foundation), outside the submitted work. 
Funding: This research did not receive any specific grant from funding agencies in the public, commercial, or not-for-profit sectors.

Author's contributions: All authors contributed to the study conception and design. Material preparation and data collection were performed by Hayato Kawachi, Motohiro Tamiya, Kinnosuke Matsumoto, Akihiro Tamiya, Takafumi Yanase, and Satoshi Tanizaki. Data analysis and interpretation were performed Hayato Kawachi and Motohiro Tamiya. The first draft of the manuscript was written by Hayato Kawachi and all authors commented on previous versions of the manuscript. All authors read and approved the final manuscript.

Acknowledgements: We are grateful to all the patients and investigators in this study.

\section{Compliance with Ethical Standards}

\section{Disclosure of potential conflicts of interest}

Hayato Kawachi reports personal fees from Ono Pharmaceutical, personal fees from Chugai Pharmaceutical, personal fees from AstraZeneca, personal fees from Taiho Pharmaceutical, personal fees from Eli Lilly, personal fees from MSD, outside the submitted work. Motohiro Tamiya reports grants and personal fees from Boehringer Ingelheim, grants and personal fees from Ono Pharmaceutical, grants and personal fees from Bristol-Myers Squibb, personal fees from Chugai Pharmaceutical, personal fees from AstraZeneca, personal fees from Taiho Pharmaceutical, personal fees from Eli Lilly, personal fees from Asahi Kasei Pharmaceutical, personal fees from MSD, outside the submitted work. HS reports personal fees from Chugai Pharmaceutical, personal fees from MSD, personal fees from AstraZeneca, outside the submitted work. Akihiro Tamiya reports personal fees from Chugai Pharmaceutical, grants and personal fees from AstraZeneca, personal fees from Boehringer Ingelheim, grants and personal fees from Ono Pharmaceutical, grants and personal fees from Bristol-Myers Squibb, personal fees from MSD, personal fees from Taiho Pharmaceutical, personal fees from Pfizer, personal fees from Eli Lilly, personal fees from Takeda Pharmaceutical, personal fees from Kissei, personal fees from Amgen, personal fees from Merck Bio Pharma, outside the submitted work. Toru Kumagai reports grants and personal fees from Ono Pharmaceutical, grants from MSD, grants and personal fees from Chugai Pharmaceutical, grants and personal fees from AstraZeneca, grants and consulting fees from Takeda Pharmaceutical, consulting fees from Nitto Denko Corporation, grants and personal fees from Eli Lilly, grants from Merck Bio Pharma, grants and personal fees from Pfizer, grants and personal fees from Boehringer Ingelheim, grants and personal fees from Taiho Pharmaceutical, personal fees from Bristol-Myers Squibb, personal fees from Novartis Pharma, grants from The Osaka Foundation for The Prevention of Cancer and Lifestyle related Diseases (Public Interest Incorporated Foundation), outside the submitted work.

\section{Research involving Human Participants and/or Animals}

All procedures performed in studies involving human participants were in accordance with the ethical standards of the institutional and/or national research committee and with the 1964 Helsinki declaration 
and its later amendments or comparable ethical standards. The study protocol was approved by the review board of each of the four institutions.

\section{Informed consent}

The patient's informed consent was waived for the retrospective nature of study, and we used an opt-out method so that patients and families could refuse to participate in the study.

\section{References}

1. Siegel RL, Miller KD, Jemal A (2020) Cancer statistics, 2020. CA Cancer J Clin 70:7-30

2. Molina JR, Yang P, Cassivi SD, Schild SE, Adjei AA (2008) Non-small cell lung cancer: epidemiology, risk factors, treatment, and survivorship. Mayo Clin Proc 83:584-594

3. Barlesi F, Mazieres J, Merlio JP, Debieuvre D, Mosser J, Lena H, Ouafik L, Besse B, Rouquette I, Westeel V, Escande F, Monnet I, Lemoine A, Veillon R, Blons H, Audigier-Valette C, Bringuier PP, Lamy R, Beau-Faller M, Pujol JL, Sabourin JC, Penault-Llorca F, Denis MG, Lantuejoul S, Morin F, Tran Q, Missy P, Langlais A, Milleron B, Cadranel J, Soria JC, Zalcman G Biomarkers France contributors (2016) Routine molecular profiling of patients with advanced non-small-cell lung cancer: results of a 1-year nationwide programme of the French Cooperative Thoracic Intergroup (IFCT).Lancet387:1415-1426. DOI: 10.1016/S0140-6736(16)00004-0

4. Reck M, Rodríguez-Abreu D, Robinson AG, Hui R, Csőszi T, Fülöp A, Gottfried M, Peled N, Tafreshi A, Cuffe S, O'Brien M, Rao S, Hotta K, Leiby MA, Lubiniecki GM, Shentu Y, Rangwala R, Brahmer JR, KEYNOTE-024 Investigators (2016) Pembrolizumab versus Chemotherapy for PD-L1-Positive Nonsmall-cell lung Cancer. N Engl J Med 375:1823-1833

5. Mok TSK, Wu YL, Kudaba I, Kowalski DM, Cho BC, Turna HZ, Castro G Jr, Srimuninnimit V, Laktionov KK, Bondarenko I, Kubota K, Lubiniecki GM, Zhang J, Kush D, Lopes G, KEYNOTE-042 Investigators (2019) Pembrolizumab versus chemotherapy for previously untreated, PD-L1-expressing, locally advanced or metastatic non-small-cell lung cancer (KEYNOTE-042): a randomised, open-label, controlled, phase 3 trial. Lancet 393:1819-1830

6. Gandhi L, Rodríguez-Abreu D, Gadgeel S, Esteban E, Felip E, De Angelis F, Domine M, Clingan P, Hochmair MJ, Powell SF, Cheng SY, Bischoff HG, Peled N, Grossi F, Jennens RR, Reck M, Hui R, Garon EB, Boyer M, Rubio-Viqueira B, Novello S, Kurata T, Gray JE, Vida J, Wei Z, Yang J, Raftopoulos H, Pietanza MC, Garassino MC, KEYNOTE-189 Investigators (2018) Pembrolizumab plus chemotherapy in metastatic non-small-cell lung cancer. N Engl J Med 378:2078-2092

7. Paz-Ares L, Luft A, Vicente $D$, Tafreshi $A$, Gümüş $M$, Mazières J, Hermes $B$, Çay Şenler $F, C$ sőszi T, Fülöp A, Rodríguez-Cid J, Wilson J, Sugawara S, Kato T, Lee KH, Cheng Y, Novello S, Halmos B, Li X, Lubiniecki GM, Piperdi B, Kowalski DM, KEYNOTE-407 Investigators (2018) Pembrolizumab plus chemotherapy for squamous non-small-cell lung cancer. N Engl J Med 379:2040-2051

8. Socinski MA, Jotte RM, Cappuzzo F, Orlandi F, Stroyakovskiy D, Nogami N, Rodríguez-Abreu D, MoroSibilot D, Thomas CA, Barlesi F, Finley G, Kelsch C, Lee A, Coleman S, Deng Y, Shen Y, Kowanetz M, 
Lopez-Chavez A, Sandler A, Reck M, IMpower150 Study Group (2018) Atezolizumab for first-line treatment of metastatic nonsquamous NSCLC. N Engl J Med 378:2288-2301

9. Nishio M, Barlesi F, West H, Ball S, Bordoni R, Cobo M, Longeras PD, Goldschmidt J Jr, Novello S, Orlandi F, Sanborn RE, Szalai Z, Ursol G, Mendus D, Wang L, Wen X, McCleland M, Hoang T, Phan S, Socinski MA, Plus A (2021) Atezolizumab Plus Chemotherapy for first-line treatment of nonsquamous NSCLC: results from the randomized Phase 3 IMpower132 trial. J Thorac Oncol 16:653-664

10. Hellmann MD, Paz-Ares L, Bernabe Caro R, Zurawski B, Kim SW, Carcereny Costa E, Park K, Alexandru A, Lupinacci L, de la Mora Jimenez E, Sakai H, Albert I, Vergnenegre A, Peters S, Syrigos K, Barlesi F, Reck M, Borghaei H, Brahmer JR, O’Byrne KJ, Geese WJ, Bhagavatheeswaran P, Rabindran SK, Kasinathan RS, Nathan FE, Ramalingam SS (2019) Nivolumab plus ipilimumab in advanced nonsmall-cell lung cancer. N Engl J Med 381:2020-2031

11. Paz-Ares L, Ciuleanu TE, Cobo M, Schenker M, Zurawski B, Menezes J, Richardet E, Bennouna J, Felip E, Juan-Vidal O, Alexandru A, Sakai H, Lingua A, Salman P, Souquet PJ, De Marchi P, Martin C, Pérol M, Scherpereel A, Lu S, John T, Carbone DP, Meadows-Shropshire S, Agrawal S, Oukessou A, Yan J, Reck M (2021) First-line nivolumab plus ipilimumab combined with two cycles of chemotherapy in patients with non-small-cell lung cancer (CheckMate 9LA): an international, randomised, open-label, phase 3 trial. Lancet Oncol 22:198-211

12. Herbst RS, Giaccone $G$, de Marinis F, Reinmuth $N$, Vergnenegre A, Barrios $\mathrm{CH}$, Morise $\mathrm{M}$, Felip $\mathrm{E}$, Andric Z, Geater S, Özgüroğlu M, Zou W, Sandler A, Enquist I, Komatsubara K, Deng Y, Kuriki H, Wen X, McCleland M, Mocci S, Jassem J, Spigel DR (2020) Atezolizumab for first-line treatment of PD-L1selected patients with NSCLC. N Engl J Med 383:1328-1339

13. Spratlin JL, Cohen RB, Eadens M, Gore L, Camidge DR, Diab S, Leong S, O'Bryant C, Chow LQ, Serkova NJ, Meropol NJ, Lewis NL, Chiorean EG, Fox F, Youssoufian H, Rowinsky EK, Eckhardt SG (2010) Phase I pharmacologic and biologic study of ramucirumab (IMC-1121B), a fully human immunoglobulin $\mathrm{G} 1$ monoclonal antibody targeting the vascular endothelial growth factor receptor-2. J Clin Oncol 28:780-787

14. Garon EB, Ciuleanu TE, Arrieta O, Prabhash K, Syrigos KN, Goksel T, Park K, Gorbunova V, Kowalyszyn RD, Pikiel J, Czyzewicz G, Orlov SV, Lewanski CR, Thomas M, Bidoli P, Dakhil S, Gans S, Kim JH, Grigorescu A, Karaseva N, Reck M, Cappuzzo F, Alexandris E, Sashegyi A, Yurasov S, Pérol M (2014) Ramucirumab plus docetaxel versus placebo plus docetaxel for second-line treatment of stage IV non-small-cell lung cancer after disease progression on platinum-based therapy (REVEL): a multicentre, double-blind, randomised phase 3 trial. Lancet 384:665-673

15. Baggstrom MQ, Waqar SN, Sezhiyan AK, Gilstrap E, Gao F, Morgensztern D, Govindan R (2011) Barriers to enrollment in non-small cell lung cancer therapeutic clinical trials. J Thorac Oncol 6:98102

16. Kawachi H, Fujimoto D, Morimoto T, Ito M, Teraoka S, Sato Y, Nagata K, Nakagawa A, Otsuka K, Tomii $\mathrm{K}$ (2018) Clinical characteristics and prognosis of patients with advanced non-small-cell lung cancer who are ineligible for clinical trials. Clin Lung Cancer 19:e721-e734 
17. Truong J, Lee EK, Trudeau ME, Chan KK (2016) Interpreting febrile neutropenia rates from randomized, controlled trials for consideration of primary prophylaxis in the real world: a systematic review and meta-analysis. Ann Oncol 27:608-618

18. Johnson DH, Fehrenbacher L, Novotny WF, Herbst RS, Nemunaitis JJ, Jablons DM, Langer CJ, DeVore RF 3, Gaudreault J, Damico LA, Holmgren E, Kabbinavar F (2004) Randomized phase II trial comparing bevacizumab plus carboplatin and paclitaxel with carboplatin and paclitaxel alone in previously untreated locally advanced or metastatic non-small-cell lung cancer. J Clin Oncol 22:2184-2191

19. Freites-Martinez A, Santana N, Arias-Santiago S, Viera A (2021) Using the common terminology criteria for adverse events (CTCAE - version 5.0) to evaluate the severity of adverse events of anticancer therapies. Actas Dermo-sifiliogr (Engl) 112:90-92

20. Eisenhauer EA, Therasse P, Bogaerts J, Schwartz LH, Sargent D, Ford R, Dancey J, Arbuck S, Gwyther S, Mooney M, Rubinstein L, Shankar L, Dodd L, Kaplan R, Lacombe D, Verweij J (2009) New response evaluation criteria in solid tumours: revised RECIST guideline, 1.1 version,Eur J Cancer45(2),228-247

21. Yoh K, Hosomi Y, Kasahara K, Yamada K, Takahashi T, Yamamoto N, Nishio M, Ohe Y, Koue T, Nakamura T, Enatsu S, Lee P, Ferry D, Tamura T, Nakagawa K (2016) A randomized, double-blind, phase II study of ramucirumab plus docetaxel vs placebo plus docetaxel in Japanese patients with stage IV non-small cell lung cancer after disease progression on platinum-based therapy. Lung Cancer 99:186-193

22. Shukuya T, Takahashi T, Kaira R, Ono A, Nakamura Y, Tsuya A, Kenmotsu H, Naito T, Kaira K, Murakami H, Endo M, Takahashi K, Yamamoto N (2011) Efficacy of gefitinib for nonadenocarcinoma non-small-cell lung cancer patients harboring epidermal growth factor receptor mutations: a pooled analysis of published reports. Cancer Sci 102:1032-1037

23. Tian W, Cao C, Shu L, Wu F (2020) Anti-angiogenic therapy in the treatment of non-small cell lung cancer. Onco Targets Ther 13:12113-12129

24. Hegde PS, Wallin JJ, Mancao C (2018) Predictive markers of anti-VEGF and emerging role of angiogenesis inhibitors as immunotherapeutics. Semin Cancer Biol 52:117-124

25. Chouaib S, Messai Y, Couve S, Escudier B, Hasmim M, Noman MZ (2012) Hypoxia promotes tumor growth in linking angiogenesis to immune escape. Front Immunol 3:21

26. Khan KA, Kerbel RS (2018) Improving immunotherapy outcomes with anti-angiogenic treatments and vice versa. Nat Rev Clin Oncol 15:310-324

27. Shiraishi Y, Kishimoto J, Tanaka K, Sugawara S, Daga H, Hirano K, Azuma K, Hataji O, Hayashi H, Tachihara M, Mitsudomi T, Seto T, Nakagawa K, Yamamoto N, Okamoto I (2020) Treatment rationale and design for APPLE (WJOG11218L): A multicenter, open-label, randomized Phase 3 study of atezolizumab and platinum/pemetrexed with or without bevacizumab for patients with advanced nonsquamous non-small-cell lung cancer. Clin Lung Cancer 21:472-476

28. Herbst RS, Arkenau HT, Bendell J, Arrowsmith E, Wermke M, Soriano A, Penel N, Santana-Davila R, Bischoff H, Chau I, Mi G, Wang H, Rasmussen E, Ferry D, Chao BH, Paz-Ares L (2021) Phase 1 
expansion cohort of ramucirumab plus pembrolizumab in advanced treatment-naive NSCLC. J Thorac Oncol 16:289-298

\section{Figures}

A

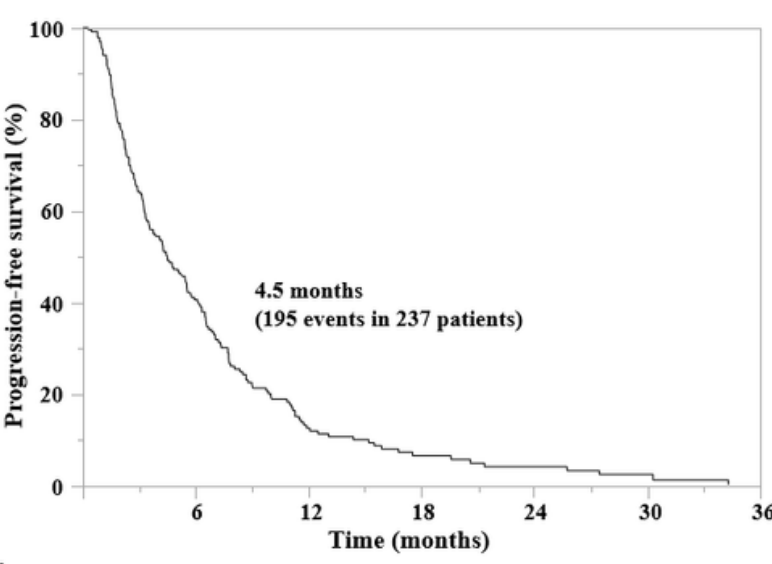

Number at risk
B

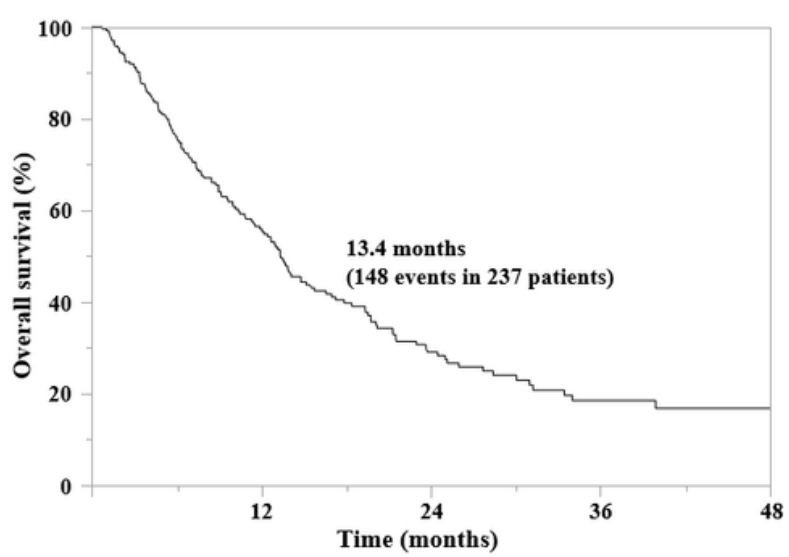

Number at risk

100

37

15

\section{Figure 1}

Kaplan-Meier survival curves showing the progression-free survival (A) and overall survival (B) of all patients.

A

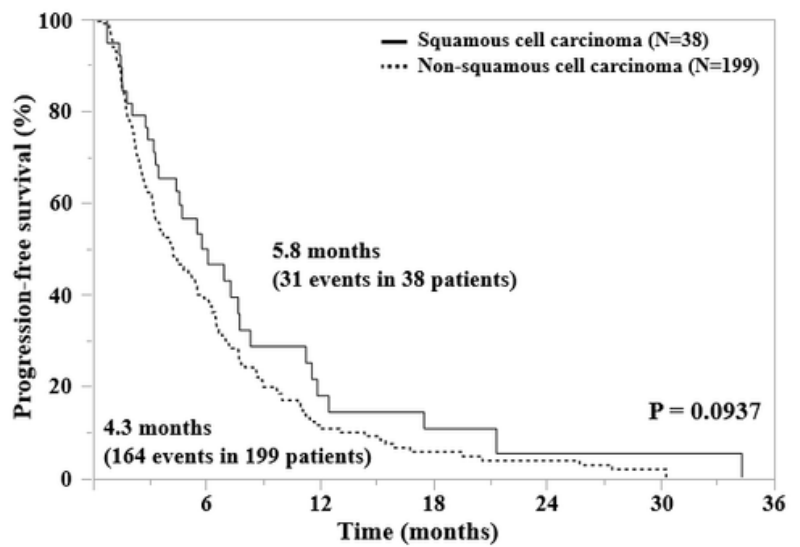

B

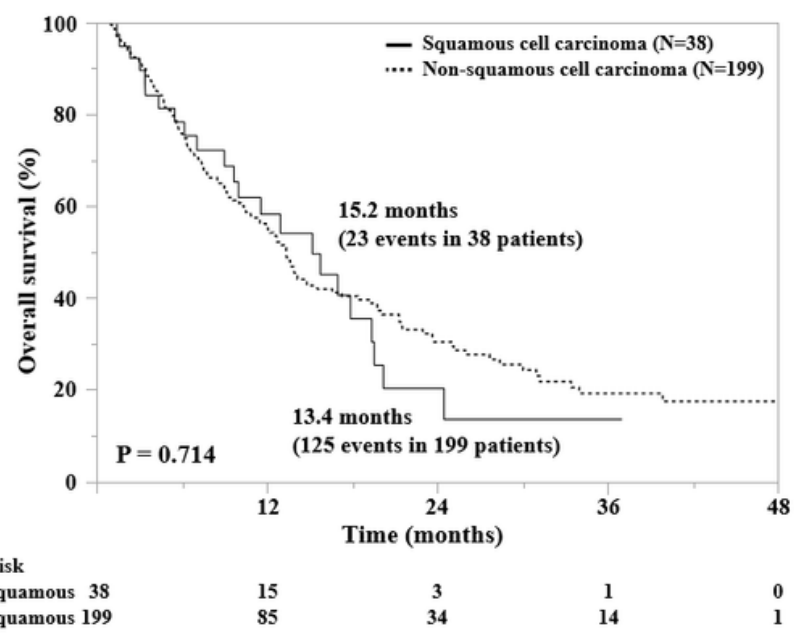

Figure 2

Kaplan-Meier survival curves showing the progression-free survival $(A)$ and overall survival (B) in $\mathrm{Sq}$ and Non-Sq patients. 